\title{
The experiences of classroom teachers on the homework process in teaching mathematics: An interpretative phenomenological analysis
}

\author{
Yusuf Ergen $^{1}$ and Mehmet Emin Durmuş ${ }^{2}$ \\ ${ }^{1}$ Kahramanmaraş Sütçü Imam University, Faculty of Education, Turkey (ORCID: 0000-0003-4313-5354) \\ ${ }_{2}^{2}$ Martyr İlhami Koçak Primary School, Erzurum, Turkey (ORCID: 0000-0003-4541-3047)
}

\begin{abstract}
This phenomenological study aimed to explore a group of classroom teachers' experiences with homework assignment in teaching mathematics. The participants of the study were 27 classroom teachers who were selected using the criterion-based sampling technique. The research data were collected with a semi-structured interview form developed by the researchers and subjected to interpretive phenomenological analysis. The results showed that the teachers plan the homework they would assign the evening before the class and use resources available on the internet while planning it. It was also revealed that they assign mathematics homework for various purposes such as ensuring comprehension of the subjects, knowledge retention and use of the learned subjects in daily life. They reported that they check and provide feedback on the assigned homework during the classes that the assigned homework is sometimes done by the family members of the students and that both preparing and checking the homework take an extensive amount of time. As a solution to these problems, they suggested communicating and negotiating with the parents, getting support from school counselors and reducing the number of the themes in the primary mathematics curriculum.
\end{abstract}

Keywords: Teaching mathematics; Math homework; Classroom teacher

Article History: Submitted 13 December 2020; Revised 10 March 2021; Published online 26 March 2021

\section{Introduction}

Homework, which plays an important role in the process of learning, is a set of practices that are carried out in order to reinforce and repeat the information that students learn at school (Doğanay et al., 2009). In terms of its historical development in education, it can be stated that homework is a phenomenon that has been constantly discussed in terms of both its positive and negative aspects. While the positive opinions put forward in the early 1900s argued that reinforcement and repetition enabled learning, the negative opinions put forward in the 1940s considered that homework interfered in the lives of both the child and the family (Chouinard et al., 2006). In the 1950s, when educators claimed that homework played an important role in the development of young people and keeping up with the advances in technology, the discussions regarding the

Address of Corresponding Author

Yusuf Ergen, PhD, Kahramanmaraş Sütçü İmam University, Faculty of Education, Department of Primary Education, 46100, Kahramanmaraş, Turkey.

$\triangle$ yergen22@gmail.com

How to cite: Ergen, Y. \& Durmuş, M. E. (2021). The experiences of classroom teachers on the homework process in teaching mathematics: An interpretative phenomenological analysis. Journal of Pedagogical Research, 5(1), 293-314. http://dx.doi.org/10.33902/JPR.2021167935 
assignment of homework started again. In the 1980s, once again it was discussed that homework should be removed from the education process, based on the idea that homework did not meet the educational needs of young people and limited their domestic life (Cooper, 2001).

With the widespread application of the constructivist approach in the 2000s, the subject of homework attracted attention yet again, resulting in the re-investigation into the effects of homework on students. In the studies conducted during these particular years it was determined that homework had positive effects on students (Brock et al., 2007; Cooper et al., 2006; Chouinard et al., 2006; Jong et al., 2000). Today, the necessity of assigning homework is considered to increase the cognitive skills of students, improve their academic success and increase communication within the family. The main focus within this scope is to assign homework in a way that does not overwhelm students (Güneş, 2014; Jerrim et al., 2019).

When the terms used to define the concept of homework (Arıkan \& Altun, 2007; Bababadoğan, 1990; Cooper, 1989; Güneş, 2014; Ok \& Çalışkan, 2019) were examined, it was observed that it was typically defined as an out-of-school activity; however, the term "out-of-school activity" was not used in some definitions at all. In this context, it can be stated that homework refers to the written or verbal activities assigned by teachers to be carried out both at and outside the school to ensure the development of students. In addition to determining the definition of homework, clarifying its purpose, types and positive and negative aspects are also important in terms of the effectiveness of the assignment process (Kütükte, 2010).

Teachers have important responsibilities in the assignment process in order to increase its effectiveness. Accordingly, they should be in contact with parents, check the homework and assign new homework that will motivate students by meeting their learning needs. When assigning students with homework, teachers should also consider the success level of the students and the options available to them in terms of the help they can receive (Landry-Cuerrier \& Migneault, 2009). The other important role that teachers play in the assignment process is preparing the content of the homework. According to Vatterott (2010), a good homework has a clear academic purpose, demonstrates the effective learning of students, promotes individual learning by offering options, can be completed by students without them requiring assistance, creates a sense of competence, and looks both fun and interesting in terms of aesthetics.

Determining the purpose and functions of homework is another significant factor of the assignment process. Van Voorhis (2004) classified the purposes of assigning homework as follows:

- Instructional Goals: to reconstruct knowledge through repetition, to prepare students for the following class, to help the personal development of students and to increase effective participation in the class.

- Communicative Goals: to improve communication between parents, teachers and students.

- Political Goals: to determine the academic criteria of the school including the frequency of homework, the role of the family and the time spent, and to clarify expectations regarding the work created by students.

Checking the homework and giving feedback is an important element that positively affects the assignment process. If these actions are not carried out, students will not be able to correct their mistakes, which in turn can lead to incorrect learning and inevitably causes the student to ignore the homework (Binbaşıoğlu, 1994). Providing feedback on assignments is important not only for students but also for teachers, who can form an idea regarding the learning situations of their students and plan their learning and teaching processes more effectively (Laud \& Patel, 2013).

It could be claimed that the main purpose of the assignment process is to enable students to learn. Good homework contributes positively to the learning process of students, while ineffective homework can have various negative effects on students. Landry-Cuerrier and Migneault (2009) stated that when the homework process is not managed well, it can be a source of stress as it can take up time both at home and at school. If the homework process creates distress in students, it can negatively affect their desire to learn. Moreover, the fact that families can provide their 
children with different opportunities regarding doing homework can lead to inequality, and, thus, homework may not always bring success.

Today, mathematics, mathematical thinking and mathematical skills are required in all professions and every part of daily life (Voinea \& Purcaru, 2015). Baki (2019) reported that mathematics classes should provide students with reasoning, modelling, attribution, communication and problem-solving skills. He also specified that teachers can help students to acquire these skills by teaching them basic mathematics concepts and the ways of acquiring mathematical knowledge. According to Yuniarti et al. (2017), teachers should encourage students to develop creative ideas when solving math problems in order to develop these skills. However, it is very difficult in mathematics education, which begins from the pre-school period, to gain these skills and make them permanent with in-class activities alone. Therefore, teachers must carry mathematics beyond their class hours and ensure that students are engaged in mathematics even outside the class. One of the easiest ways to do this is by assigning them mathematics homework.

Primary school mathematics homework is important in terms of ensuring that students acquire basic mathematical skills permanently, discover the equivalence of these skills in daily life, develop a positive attitude towards mathematics, and above all, gain mathematical thinking skills. Sousa et al. (2017) concluded that mathematics played a fundamental role in academic achievements and problem-solving skills of children. Therefore, mathematics homework is expected to improve students' problem-solving skills critical and analytical thinking skills, as well as their academic success.

Mathematics is the basis of many disciplines. According to Kabapinar and Yilmaz (2020), students' success in mathematics class also affects their success in other classes as mathematics equips them with four operational skills as well as the flexibility of thinking, reasoning, problem solving and many metacognitive thinking skills. Therefore, starting from the first years of education, teachers should place more importance on mathematics classes and the homework for these classes. The foundation of the high-level thinking skills of students can be established with mathematics homework assigned during primary school. Primary school teachers are expected to be aware of this when assigning mathematics homework and give homework that will improve these skills.

Some studies in the literature concluded that when assigning homework classroom teachers aimed to ensure permanent learning (Baynazoğlu, 2019) and to encourage a sense of duty and responsibility in students (Ok \& Çalışkan, 2019), assigned homework that was of a reinforcing and repetitive characteristic (Baynazoğlu, 2019; İflazoğlu \& Hizmetçi, 2006; Medwell \& Wray, 2018; Ok \& Çalışkan, 2019; Özer \& Öcal, 2013), provided detailed feedback (Baynazoğlu, 2019; Özer \& Öcal, 2013) and only checked if the homework was done or not (Iflazoğlu \& Hizmetçi, 2006). In addition, some studies indicated that the teachers thought that students feelings towards homework vary according to the type of homework and were of the opinion that homework increases academic success (Baynazoğlu, 2019; Büyüktokatl1, 2009; Medwell \& Wray, 2018). In these studies, the classroom teachers' views on homework were examined regarding different variables such as purpose of assigning homework, homework type, checking homework and benefits of homework. It was determined that the studies mostly focused on the homework phenomenon rather than the class context. The studies that examined teachers' views on homework within the context of mathematics class were mostly conducted with a focus on the relationship between homework practices and mathematical achievement rather than the homework process itself. Most of these studies revealed that homework positively affected academic achievement in mathematics classes (Cooper et al., 2006; Fernandez-Alonso et al., 2015; Güven \& Akçay, 2019; Jong et al., 2000; Kaplan, 2018; Medwell \& Wray, 2018; Ok \& Çalışkan, 2019; Nunez et al., 2015; Rosairo et al., 2015; Tertemiz, 1991; Xu et al., 2014). Lastly, Abdelfettah and Lam (2018) reported no relationship between homework practices and mathematical success of the students.

The present study aimed to examine the experiences of classroom teachers regarding the homework process in mathematics classes. For this purpose, the following questions were raised: 
How do classroom teachers implement the homework process in mathematics classes? What are classroom teachers' experiences regarding problems they face during the math homework process?

\section{Method}

In this section, detailed information is given about the research model, the participants, the data collection tools used in the research, the collection and analysis of the research data.

\subsection{Research Design}

The present study was conducted using the phenomenological design as it aimed to examine the experiences of classroom teachers regarding the homework process in mathematics classes. The aim of phenomenological studies is to determine the meaning formed by the experiences (Ersoy, 2016). Phenomenology focuses on what people experience and how they interpret the world. Accordingly, with this design the attempt is to describe how the phenomena was experienced, and therefore, studies that are conducted using the phenomenological design are performed on people who directly experienced the phenomena (Patton, 2002/2018).

The process of conducting a phenomenological study is as follows: a phenomenon that was experienced is determined as the problem and research is performed on a few individuals with shared experiences. The data are collected mostly in the form of interviews and meaning units are created in the data analysis step. Finally, a comprehensive description of the data is created (Creswell, 2013).

In the present study, the assignment process for mathematics classes was determined as the phenomenon and the process was examined within the context of the experiences of primary school teachers.

\subsection{Participants}

The present study was conducted with 27 Turkish primary school teachers who were active during the 2019-2020 academic year. The criterion sampling technique, a purposeful sampling method, was used to determine the participants. The main purpose of the criterion sampling technique is to examine situations that meet various predetermined criteria (Emaikwu, 2011). Participants were determined according to the criteria of "having teaching experience for 5 years or more" in order to show that professional experience was important in terms of the study. The participants were teachers working at different schools. The real names of the participants were kept confidential and each participant was given a pseudonym suitable to their gender. The demographic information of the participants is presented in Table 1.

As can be seen from Table 1, 22 of the participants were male and five were female. It was determined that 17 of the participants had children. In this context, it was observed that 10 participants had children who were not registered to any school, one participant had a child of kindergarten level and eight participants had children of primary school level. The children of four of the participants were receiving post-primary school education. In other words, 12 of the participants had children who had received primary school education and were continuing their education. Most of the participants had 5 to 10 years of professional experience, while three of the participants had 11 to 15 years of experience, five of them had 16 to 20 years of experience, and two of them had 20 and 25 years of experience. Most of the participants had 10-15 students or 1630 students in their classes, while six participants had 16-20 students, four participants had 21-25 students, two participants had 30-35 students and one teacher had 25-40 students in their classes. Twenty-three of the participants taught in separate classrooms, while four participants taught in combined classrooms. 
Table 1

Demographic characteristics of the primary school teachers

\begin{tabular}{|c|c|c|c|}
\hline & & Pseudonyms & $n$ \\
\hline \multirow[t]{2}{*}{ Gender } & Male & $\begin{array}{l}\text { Naim, Atilla, Kadir, Murat, Cenk, Anıl, Ersin, } \\
\text { Ahmet, Berk, Atakan, Onur, Sinan, İrfan, } \\
\text { Ömür, Orhan, Mesut, Ferdi, Can, Musa, Mert, } \\
\text { Oğuz, Fatih }\end{array}$ & 22 \\
\hline & Female & Fatma, Seda, Sema, Hilal, Emel & 5 \\
\hline \multirow[t]{2}{*}{$\begin{array}{l}\text { Do they have } \\
\text { children? }\end{array}$} & Yes & $\begin{array}{l}\text { Atilla, Murat, Ersin, Ahmet, Sinan, İrfan, } \\
\text { Ömür, Orhan, Mesut, Musa, Mert, Oğuz, } \\
\text { Fatih, Seda, Sema, Hilal, Emel }\end{array}$ & 17 \\
\hline & No & $\begin{array}{l}\text { Naim, Kadir, Cenk, Anıl, Berk, Atakan, Onur, } \\
\text { Ferdi, Can, Fatma }\end{array}$ & 10 \\
\hline \multirow{4}{*}{$\begin{array}{l}\text { Educational } \\
\text { Level of their } \\
\text { children }\end{array}$} & $\begin{array}{l}\text { Not registered } \\
\text { to school }\end{array}$ & $\begin{array}{l}\text { Atilla, Murat, Ersin, Musa, Fatih, Sema, Hilal, } \\
\text { Mesut }\end{array}$ & 8 \\
\hline & Kindergarten & Sinan, & 1 \\
\hline & Primary school & $\begin{array}{l}\text { Ersin, Ahmet, Sinan, İrfan, Ömür, Orhan, } \\
\text { Seda, Hilal, }\end{array}$ & 8 \\
\hline & $\begin{array}{l}\text { Post-primary } \\
\text { school }\end{array}$ & Emel, Fatih, Mert, Oğuz & 4 \\
\hline \multirow{4}{*}{$\begin{array}{l}\text { Professional } \\
\text { Experience }\end{array}$} & $5-10$ years & $\begin{array}{l}\text { Naim, Atilla, Kadir, Murat, Fatma, Cenk, Anıl, } \\
\text { Berk, Atakan, Onur, Sinan, Ferdi, Can, Musa, } \\
\text { Seda, Sema, Oğuz }\end{array}$ & 17 \\
\hline & $11-15$ years & Mesut, Orhan, Fatih & 3 \\
\hline & 16-20 years & Ersin, Ahmet, Ömür, İrfan, Hilal & 5 \\
\hline & 20-25 years & Mert, Emel & 2 \\
\hline \multirow{6}{*}{ Class size } & $10-15$ students & $\begin{array}{l}\text { Naim, Atilla, Murat, Fatma, Ömür, Mesut, } \\
\text { Sinan, }\end{array}$ & 7 \\
\hline & $16-20$ students & Kadir, Berk, Orhan, Ferdi, Musa, Emel & 6 \\
\hline & $21-25$ students & Cenk, Ahmet, Atakan, İrfan, & 4 \\
\hline & $26-30$ students & Anil, Ersin, Onur, Can, Mert, Sema, Hilal & 7 \\
\hline & 30-35 students & Seda, Oğuz & 2 \\
\hline & 36-40 students & Fatih & 1 \\
\hline
\end{tabular}

\subsection{Data Collection Tool}

In this study, the interview method, a qualitative research method, was used for data collection. The data were obtained through a semi-structured interview form developed by the researchers.

When developing the data collection form, firstly the relevant literature was reviewed and a conceptual framework was created in order to ensure internal validity. In order to ensure the content and structure validity of the form, the opinions of two primary school teachers and one academic expert were elicited. Initially, the first version of the interview form consisted of 10 questions. However, the scope of the questions was reduced and a total of five questions, which included probe questions, were created in line with the opinions of the two primary school teachers and the academic expert. A pilot application was carried out with three primary school teachers using the final version of the interview form and as a result it was determined that there was no need to make any changes to the research questions.

The interview form consisted of the following questions:

(1) Do you prepare before assigning homework for math class?

(2) What is your purpose when assigning homework for math class?

(3) How do you evaluate the homework you assign for math class? 
(4) What problems do you experience during the math homework process?

(5) What are your opinions regarding solving the problems you face during the math homework process?

\subsection{Data Collection}

This study was initiated during the COVID-19 pandemic, which has been spreading rapidly around the world. As the schools were closed down by the Turkish Ministry of National Education [MoNE] only one week after the initiation of the study, the opportunities to contact the participants of the study were restricted. For this reason, all of the interviews were conducted online in the form of video recordings.

The principals of the schools in which the participant teachers taught helped the researchers to contact the participants. Accordingly, meeting dates were set with the participants over the phone. Prior to the interviews, the participants were informed about the purpose and importance of the study and assured that their answers would never be used for any other purposes. The interviews were completed within a period of six weeks. The duration of the interviews ranged from 25 minutes to 37 minutes. Within the scope of the study, a total of 735 minutes of video interviews were conducted with the 27 participants. The interview recordings were transmitted to a computer environment on the same day they were conducted.

All conspicuous statements and facial expressions of the participants during the interview process were noted by one of the researchers in parentheses on the interview form. In order to reduce data loss and increase the reliability of the study, the data obtained from the video interviews were sent to the participants by e-mail one day after they were transcribed, and the participants were asked to confirm their views and state if there was anything else they would like to add. In this context, two of the participants stated additional opinions and provided feedback by e-mail.

\subsection{Data Analysis}

In this study, the data were analyzed using the interpretative phenomenological analysis (IPA) method, which focuses on examining the meanings rooted in people's life experiences (Ersoy, 2016). IPA aims to clarify the essence and structure of the experiences of a group of people regarding a phenomenon and what this experience means to them (Patton, 2002/2018). According to Sart (2015), IPA focuses on how people attribute meanings to their experiences. Smith et al. (1999) reported that participants should be approached as cognitive, linguistic, emotional and physical entities, considering that the verbal expressions of the participants and their cognitive and emotional states are related in IPA. According to Lopez and Willis (2004), researcher's prior knowledge is one of the basic assumptions of IPA in terms of making sense of participant expressions. Therefore, the fact that one of the authors of the study is working as a primary school teacher and the other researcher has been working as a faculty member in the department of classroom teaching and previously worked as a primary school teacher, which was considered as an advantage in terms of using IPA.

After all the interviews were transcribed and approved by the participants, the irrelevant parts were removed from the texts. The data was analyzed in accordance with the interpretive phenomenological analysis steps proposed by Smith et al. (2013), namely reading and rereading, initial note-taking, developing themes, searching for connections between emerging themes, moving to the next situation and searching for patterns between situations. The code, category and themes that were created by the researchers and supported by direct quotations taken from the interviews. Each code, category, and theme was created by discussing and reaching consensus among researchers. Then, they were cross-checked. In order to interpret the findings better, it was decided to leave some attachments in the naming of the theme titles and to make changes on the categories reached under only one theme. 


\section{Results}

In the study, the opinions of the participants regarding the homework process in the mathematics class were categorized under four themes: "Planning", "Purpose of Homework", "Evaluation" and "Problems Encountered and Suggested Solutions" (Figure 1).

Figure 1

The themes regarding the homework process in math class

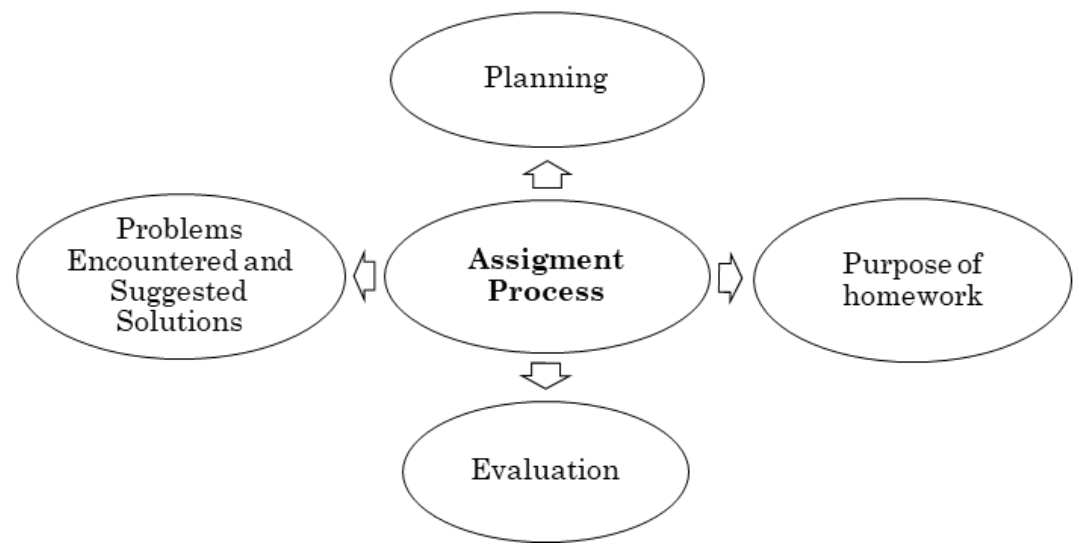

In the planning theme, the teachers specified the time they spent planning the homework, the resources they used, what criteria they had to determine the homework, in what way and how often they assigned homework, and how long the homework took. In the purpose theme, they carried out evaluations regarding the functions and types of homework they assigned. In the assessment theme, they shared their experiences regarding the time spent checking homework, how they gave feedback for homework, what tools they used to evaluate homework, and their reward or punishment approaches for homework. In the problems encountered and suggested solutions theme, the participants specified the problems they experienced during the assignment process and how they found solutions to these problems. The scope of these themes is presented below.

\subsection{Results Regarding the Planning Process}

The codes reached regarding this theme were grouped around four categories as "planning time", "resources used", "determination criteria" and "format of giving homework." The specified categories and the codes that determine these categories are presented in Table 2.

Table 2

Categories and codes related to the planning theme

\begin{tabular}{|c|c|c|c|}
\hline Planning time & Resources used & Determination criteria & $\begin{array}{c}\text { Format of giving } \\
\text { homework }\end{array}$ \\
\hline A day before & $\begin{array}{l}\text { Online } \\
\text { resources }\end{array}$ & Compatibility to overall level & Photocopy \\
\hline During class & Source book & $\begin{array}{l}\text { Being able to do it by } \\
\text { themselves }\end{array}$ & \\
\hline \multirow[t]{7}{*}{$\begin{array}{l}\text { On the } \\
\text { weekend }\end{array}$} & Textbook & $\begin{array}{l}\text { Taking a short time to } \\
\text { complete }\end{array}$ & \\
\hline & & Frequency of the homework & \\
\hline & & Personal differences & \\
\hline & & Different question types & \\
\hline & & Being interesting & \\
\hline & & $\begin{array}{l}\text { Compatibility with the } \\
\text { outcome }\end{array}$ & \\
\hline & & From easy to hard & \\
\hline
\end{tabular}


In the study, it was determined that almost all of the teachers planned the mathematics homework the night before the class, while some planed during class stating that they did not spare much time for homework planning. One of the teachers, Mr. Musa expressed this situation as "I arrange the homework the night before I give it. If the homework (pauses), the purpose of the homework is also important here, but I cannot say that I normally spend too much time on it." Another teacher, Mr. Cenk expressed it as "I usually arrange the homework during class. But sometimes I prepare homework a day before class." The teachers who prepared homework the earliest stated that they prepared it during the weekend before the class. They justified it stating that they had more time to plan at the weekend. One of the teachers, Mr Naim expressed this situation as "Before class, I usually try to prepare for the next class at the weekends when I have plenty of time. Homework planning is also included in my class preparation activity."

All of the teachers stated that they made use of online sources when planning their mathematics homework. They stated that they followed the websites they liked, downloaded activity samples from these sites and assigned these activities as homework. For example, Mr. Can stated how he made use of internet resources as "I keep track the websites of the teachers that I appreciate. If there are any good activities on the sites, I download them and distribute the activity sheets to the children." Some teachers stated that they prepared math homework by using source books and mathematics textbooks in addition to Internet sources. Contrary to the fact that some of the teachers assigned homework using the textbook, some teachers stated that they did not use the textbook due to the fact that the it only contained a small number of questions and abruptly moved from easy questions to difficult questions. For example, Mr. Anil stated his reason for not using mathematics textbooks as "I mean, the activities in the books are not very much, so the students do them quickly, I mean, there are two questions on a page and it is done instantly." It is striking that the teachers who stated that they used internet resources did not mention the homework activities in the Education, Informatics Network (EBA) portal, which the Ministry of National Education offers to students and teachers free of charge. In this context, it was observed that Internet resources were important for the participants in the assignment process, but the EBA portal was not preferred that much by the participants.

It was observed that the teachers took into account various criteria when planning mathematics homework. These homework criteria can be compiled as follows: being appropriate for the average level of the class, allowing students to do it by themselves with little help from others, not taking more than an hour, assigning homework right after class, and observing individual differences. Teachers who planed homework according to the average level of the class stated that they avoided variation in the homework. Ms. Seda pointed out that:

I make sure that my homework matches the average level of the class. This is because I don't prepare a different homework for each student, but give everyone the same. My homework is neither too difficult nor too easy it is suitable for the general level.

Teachers who cared about planning homework in a way that students could do it by themselves emphasized that otherwise the homework lost its function. Mr. Kadir, one of these teachers, stated his experiment as:

I think the most important point is the homework that students can do. The students may find the homework difficult in various parts but they should be able to do it even with a little help from others, otherwise the homework has no meaning. The student should be able to do the homework by himself.

Some of the teachers who focused on the amount of time the homework took emphasized that the this time should not exceed half an hour noting that this is not to bore the students with the mathematics homework. It should be noted that all of the teachers who held this view had at least one school-age child. It was observed that these teachers cared about this criterion as they experienced this issue with their own children at home. For example, Mr. Ahmet stated his experience on this issue as: 
I am a parent and sometimes my child has 15 pages of homework a day. I generally complete his homework and write notes to his teacher about the parts of the homework I did. That is why, I try to give homework that will not take much time. In other words, I try to assign homework that only takes a maximum of half an hour, an hour, but I assign some every day. This frequency of homework helps students reinforce the information better. There is no point in boring a student with the mathematics homework.

The teachers who cared about the frequency of assigning homework as a criterion stated that homework should be given after each class, albeit in small amounts. Moreover, some teachers stated that they took into account the following criterions: considering individual differences, including different question types, including images in homework to attract attention, being suitable to the acquisitions and going from easy to difficult.

All of the teachers stated that they assigned homework to the students in the form of A4 paper size photocopy sheets. Some of the teachers explained the reason for this method as the limited technological facilities in the districts where they lived. It can be stated that teachers try to provide equal opportunities to the students vie photocopying. For example, Mr. Sinan stated that:

I print it out an A4 size paper and distribute it that way. This is better than having everyone buy a book. Moreover, this is a village school, nobody has internet at home. That why we do it like that, otherwise we would not be able to provide equal opportunities. Every student should have equal opportunities, so that we can assign homework accordingly.

\subsection{Results Regarding the Purpose of the Homework}

The codes determined according to this theme were collected within two categories as "Function" and "Type". The specified categories and the codes that determined the categories are presented in Table 3.

Table 3

Categories and codes related to the theme of Purpose of Homework

\begin{tabular}{|c|c|c|}
\hline \multicolumn{2}{|c|}{ Function } & Type \\
\hline Understanding the subject & Gaining practicality & Reinforcement \\
\hline $\begin{array}{l}\text { Ensuring the retention of } \\
\text { information }\end{array}$ & Acquiring self confidence & Repetition \\
\hline Being useful in daily life & Establishing peer communication & $\begin{array}{l}\text { Preliminary } \\
\text { preparation }\end{array}$ \\
\hline $\begin{array}{l}\text { Encouraging a sense of } \\
\text { responsibility }\end{array}$ & Providing individual learning & \\
\hline $\begin{array}{l}\text { Ensuring the development of } \\
\text { problem solving skills } \\
\text { Gaining the ability to multi- } \\
\text { directional thinking }\end{array}$ & $\begin{array}{l}\text { Establishing communication } \\
\text { between family and child }\end{array}$ & \\
\hline
\end{tabular}

According to the findings of the study, all of the teachers assigned homework in mathematics class, with most of them aiming to fulfill functions such as understanding the subject, ensuring the retention of information and being useful in daily life. While Mr. Atilla explained the purpose of assigning the mathematics homework as, "The children learn at school but when they don't repeat what they've learnt at home, they have trouble understanding subjects." Mr. Oguuz stated that, "Homework helps them retain the knowledge they have learned. Student can forget what they have learned, but when they repeat it at home with homework, they tend to retain it.", Naim teacher expressed it as "Homework should be able to be used in the student's daily life. Thanks to the homework they do, students should be able to say that they can solve the problems they encounter." Some teachers were of the view that the function of homework should be to ensure that students gain responsibility, improve their problem solving skills, develop multidirectional thinking ability, practicality, self-confidence, to provide peer communication and individual learning and to facilitate their communication with their family members. It was observed that 
teachers cared about the personal development of the students as well as their academic development in terms of the function of homework. However, they tended to assign homework in order to increase the skills related to academic development.

It was determined that the aim teachers had when assigning homework varied according to the type of homework. Almost all of the teachers stated that they assigned homework in order to reinforce the subject by repetition. Some teachers reported that they assigned homework to prepare the students for the next subject and most of these teachers emphasized that they also aimed to reinforce learning through homework. In terms of homework types, it was observed that the teachers tended to assign homework to reinforce students' learning because they focused on the retention of the subject. For example, Mr. Murat expressed his experiences as "A general repetition must be carried out at home to reinforce all the information learned at school. This is what I assign my mathematics homework for." Although this was perceived as a positive situation, it was also considered that it may distract the students from discovering and constructing knowledge on their own.

\subsection{Results Regarding the Homework Evaluation Process}

The codes obtained regarding this theme are divided within five categories as "Checking Time", "Feedback Type", "Tools and Equipment", "Rewards" and "Punishments". The specified categories and the codes that determined the categories are presented in Table 4.

Table 4

Categories and codes related to the Evaluation of Homework

Checking

Time

During class

During break

\begin{tabular}{l} 
Feedback Type \\
\hline Correcting \\
individual mistakes \\
Correcting general \\
mistakes
\end{tabular}

Just checking homework

Tools and
Equipment

Class board

Smart board

Mobile phone

\begin{tabular}{l} 
Rewards \\
\hline Star chart
\end{tabular}

Punishments

Type two
punishment
Redoing the
same
homework
Informing
parents

Most of the teachers stated that they checked homework during class, while some of them stated they checked them during the breaks in order to not interrupt the flow of the class. Most of the teachers who checked the homework during class emphasized that the checking process takes too much time. Ms. Hilal stated that, "We review the homework with the students in math class, of course, it takes a long time. But it is definitely checked no matter how much it affects the teaching of the class in terms of time." It was determined that all of the teachers attached significance to checking homework, but they thought that checking homework negatively affected class hours. Mr. Naim, who checks the math homework during breaks, expressed this situation as "We have 20-minute breaks and I assess the homework between breaks so that it doesn't take up time during class."

It was determined that almost all of the teachers gave feedback for the homework by correcting mistakes. In this context, some of the teachers stated that they gave feedback to individual students on their mistakes, while some stated that they only corrected common mistakes. Some of teachers stated that they only checked whether the homework was done and did not give any feedback to the students regarding their mistakes. Teachers who avoided giving individual feedback to incorrectly done homework, were of the view that doing so would negatively affect class time. For example, Mr. Murat, who corrected only common mistakes, stated that, "We correct the common mistakes, because otherwise there would be no time left for the subjects to be taught. It takes too much time to give feedback to every student. I particularly give feedback in math class." Some of the teachers stated that they gave detailed feedback only for the mathematics homework and only 
gave feedback in terms of scoring answers as true or false for other classes. Mr. Ersin, give feedback to mistakes individually, stated that, "I correct everyone's mistakes one by one. Even though it takes time, I try to do this, especially for mathematics homework. So I can't say that I achieved this very much in other class. But, feedback is important in mathematics." It was assessed that the participants placed importance on and practiced giving feedback to incorrectly done math homework.

It was determined that some of the teachers provided feedback for homework by writing the answers of the homework questions on the class board. Mr. Sinan, one of the participants, asserted that, "I explain the solution to questions of homework on the board. Those who have made mistakes check the right answers from the board." Some teachers stated that they solved the incorrectly answered questions together with the students by on the smart board or checked them at home after taking pictures of the homework sheets on their mobile phones. The teachers who used mobile phones to provide feedback emphasized that they aimed to save time in class by doing this. Mr. Kadir explained that "I usually take pictures of students' math homework on my cell phone. Then I check them at home. So I save time." It was assessed that the teachers required alternative homework evaluation methods in order to save time in class.

It was observed that some teachers used symbolic rewards in order to reinforce the students who completed their homework successfully. Some of the teachers stated that they used a star chart in this context, while some stated that they drew a plus sign on the homework sheets. Ms. Emel asserted that, "I have star charts that I created. So, I give stars to the students who do their homework to encourage them."

Some of the teachers stated that they applied various punishments if homework was not done. It was observed that teachers usually applied a type two punishment to the students if they did not complete their homework. These teachers stated that the students who did not do the homework were asked to complete the homework during the break or social activity classes, while the other students were rewarded for doing their homework. For example, Mr. Saffet pointed out that, "I definitely make students complete the homework during that day. So, students work on their homework during the break while their classmates are on break." Another teacher, Mr. Atilla explained that, "The most important thing here is to reward other students instead of a punishment. Maybe this could even be a good job. I think this is the greatest punishment." Some teachers stated that in cases when homework is not done; they assigned the same homework again to be done at home and informed the parents. Regarding the evaluation of homework, it was observed that the teachers tended to apply punishments for incomplete homework instead of rewards for complete homework.

\subsection{Results Regarding the Problems Encountered and Suggested Solutions}

Regarding this theme, the codes determined in the context of the problems encountered were grouped around three categories: "Family Based", "Student Based" and "Time Based". The suggested Solutions for each category were specified under the codes. The specified categories and the codes of the categories are presented in Table 5.

It was observed that the teachers usually face problems regarding the families of students and thought that the homework that could be done by students was being done by family members. As a solution to this problem, a significant number of the teachers suggested that the teachers should be in contact with the family and inform them about giving limited support for homework, while very few teachers suggested getting help from the school counselor in relation to the families. For example, Mr. Ömür proposed a solution as "I think we should talk to families, visit parents and inform them that the students should be the ones doing the homework and that they should only provide support. Within this context, help can be required from school counsellors." 
Table 5

Categories and codes related to the theme of Problems Encountered and Suggested Solutions

\begin{tabular}{|c|c|c|}
\hline $\begin{array}{l}\text { Family Based Problems and } \\
\text { Suggested Solutions }\end{array}$ & $\begin{array}{l}\text { Student Based Problems and } \\
\text { Suggested Solutions }\end{array}$ & $\begin{array}{l}\text { Time Based Problems and } \\
\text { Suggested Solutions }\end{array}$ \\
\hline $\begin{array}{l}\text { Doing homework with the } \\
\text { help of family members }\end{array}$ & Ignoring homework & $\begin{array}{l}\text { Homework preparation } \\
\text { taking too much time }\end{array}$ \\
\hline $\begin{array}{l}\text { Suggested solutions } \\
\bullet \quad \text { Cooperation with } \\
\text { family }\end{array}$ & $\begin{array}{l}\text { Suggested solutions } \\
\bullet \quad \text { Assigning homework } \\
\text { according to } \\
\text { individual differences }\end{array}$ & $\begin{array}{l}\text { Suggested solutions } \\
\qquad \quad \text { Simplification of the } \\
\text { curriculum }\end{array}$ \\
\hline $\begin{array}{l}\text { - Support by school } \\
\text { counselor }\end{array}$ & $\begin{array}{l}\text { - Assigning less } \\
\text { homework }\end{array}$ & $\begin{array}{l}\text { Checking homework takes too } \\
\text { much time }\end{array}$ \\
\hline Educational level of family & $\begin{array}{l}\text { - Assigning interesting } \\
\text { homework }\end{array}$ & Suggested Solutions \\
\hline Indifference of Family & $\begin{array}{l}\text { - Applying a type two } \\
\text { punishment } \\
\text { - Giving feedback } \\
\text { during class } \\
\text { - } \text { Following up the } \\
\text { homework with the } \\
\text { family } \\
\text { Not being able to solve } \\
\text { problem-type questions } \\
\text { Suggested Solutions } \\
\text { - Creating question } \\
\text { activities } \\
\text { - Diversifying } \\
\text { - } \text { questions } \\
\text { Personal differences }\end{array}$ & $\begin{array}{l}\text { - Checking homework } \\
\text { at home } \\
\text { - Focusing on successful } \\
\text { students } \\
\text { - Checking the } \\
\text { homework during } \\
\text { social activity classes }\end{array}$ \\
\hline
\end{tabular}

Some of the teachers expressed that the problems they encountered were related to the low educational level and the indifference of the family. For example, Mr. Ahmet stated that, "Sometimes children cannot get help from their family at home as they don't understand the subject or families teach their children by means of their own knowledge. So, the educational status of the family is also important." However, the teachers did not suggest any solutions regarding either issue.

It was observed that teachers also encountered problems that occurred from the students. Students not caring about homework was considered to be an important problem by the teachers. For example, Ms. Sema expressed her thoughts as "Students lack sense of responsibility or duty and do not think to themselves. Unfortunately, students don't care about homework." The teachers suggested the following solutions: assigning short and interesting homework according to individual differences, applying a type two punishment, providing feedback to homework in the classroom and cooperating with families regarding homework assignments. For example, Mr. Atilla expressed his proposal as "Students don't care about homework. In terms of a solution the students should be grouped according to their levels, individual differences and assigned homework accordingly". However, another teacher Mr. Mesut expressed his proposal as "When homework is less, students are more enthusiastic about math homework so I prefer to give them short assignments." The teachers were of the view that the family's approach to homework affected the student's approach to homework as students were determined to stop caring about homework if they observed that their families didn't care. Another teacher, Mr. Ersin asserted that, 
"If the student's family is already helping, the student also cares about the math homework. If the family is not interested, the student does not care."

Some of the teachers complained that the students were unable to answer problem solving questions. In this context, the teachers thought that the students had difficulties in understanding the questions and that they were unable to use the new knowledge in solving a new problem because of their rote knowledge. Mr. Kadir pointed out that:

Children have difficulty in understanding problems and also face difficulties in doing problem related math homework. They can do the homework based on rote-knowledge easier but when we ask questions at an analytical level or higher, children find them difficult to solve. They were unable to use the knowledge in solving a new problem.

Regarding this issue, some of the teachers suggested that the students should create problem questions, while others stated that diversifying the questions and providing feedback to the them in class would be beneficial. For example, Mr. Mert proposed that, "In terms of a solution, for example, I assign them to create a problem question."

In addition to these problems, some teachers stated that they faced problems resulting from students with individual differences in their classrooms. The teachers stated that having inclusive students especially in the mathematics class made it difficult to give homework. Ms. Emel asserted that, "There are students with special needs in the class, there are students at different levels and it is difficult to assign math homework according to these differences."

Some of the teachers were observed to have time-based problems. The teachers stated that homework preparation and checking homework require a lot of time. For instance, Ms. Emel pointed out that, "There are students with different levels in my class and it takes a lot of time to sit down and prepare different assignments. It is tiring." Besides, Fatih expressed this problem as "The most difficult aspect of math homework for a teacher is checking it. Because if you check it in school, it takes a lot of time." Some teachers suggested simplifying the mathematics curriculum in order to reduce the time spent on homework preparation. In terms of the excessive time spent on checking homework, the teachers suggested that they could take the homework home to check it, focus on the successful students rather than all of the students or check the math homework during social activity classes. For instance, Mr. Mert expressed his proposal as "I try to check homework at home rather than in class, my phone camera is enough for me. This is my own solution to this issue." Another teacher, Mr Onur outlined his proposal as "I think we should devote our time to successful students because they want to learn more and are more enthusiastic. Not every student has this enthusiasm." Besides, some of the teachers proposed to checking the math homework during social activity classes.

\section{Discussion and Conclusion}

The opinions of the classroom teachers regarding the assignment process of mathematics teaching were discussed around four themes: Planning, purpose of homework, evaluation, and problems encountered and suggested solutions.

\subsection{Planning Process}

It was observed that all of the teachers participating in the study prepared for homework. At first sight this can be evaluated as a positive situation. However, the fact that most of the teachers prepared homework in short periods of time such as the evening before the class or during class may not be evaluated positively in terms of their homework understanding. This may have a negative effect on the quality of homework. Some teachers, on the other hand, stated that they prepared at the weekend because they had more time to spare. These teachers stated that they cared about homework and spent extra time on it. In this context, it was determined that excluding the ones who prepared homework at the weekend, the teachers did not spend much time for the preparation process. It can be stated that especially the teachers who prepared homework at the end of class and those who assigned homework at the same time as teaching a subject squeezed 
homework planning into a very limited time.

It was determined that in general all of the teachers used Internet sources for homework preparation. Within this context, they used the activity examples on websites as homework. It was found to be striking that the teachers did not prepare the homework themselves. It was revealed that EBA, which is the official education portal of the Ministry of National Education, was used not preferred that much by the participants for assigning homework. However, web-based learning applications offer new opportunities for education, and it is observed that these applications are being used widely today (Chandra \& Fisher, 2009). Dağ (2012) examined the effects of sharing mathematics homework using online environments on primary school students and concluded that homework provided on online increased the learning of students and their interest in the class. Serhan and Almeqdadi (2019) examined web-based homework programs that provide instant feedback for mathematics classes and reported that these programs facilitated the teacherstudent relationship and enabled the understanding of mathematical concepts. Albelbisi and Yusop (2018) and Yildirım et al. (2017) determined that the use of web-based programs in mathematics homework positively affected the attitudes of students towards homework and increased their motivation. The use of such applications has especially increased during the Covid19 pandemic. However, their functionality has also been a subject of discussion. Some of the participants of the present study stated that they used the activities in source books as homework. Very few teachers stated that they used the textbook for homework, while the others stated that they preferred not to use textbooks as homework sources as they only contain a small number of questions, which are not graded from easy to difficult.

It was observed that when preparing homework assignments most of the teachers paid attention to the homework being appropriate for the average level of the class, being at a level that students could complete with little help from others, and being suitable to personal differences. According to Landry-Cuerrier and Migneault (2009), the academic level of students in mathematics homework must be considered. Rowell and Hong (2002) also argued that homework that is not suitable for the levels of the students can cause students to develop a negative attitude towards homework. Accordingly, some teachers stated that it would be more meaningful to prepare homework that the students would be able to do on their own or with only a little help from others. It was assessed that the fact that the participants considered the levels of the students when preparing the mathematics homework was a positive approach in terms of achieving the purpose of the homework. However, it can be stated that preparing the homework according to average level of the class can negatively affect the students who have personal differences compared to rest of the class. The teachers also stated that they focused on assigning homework that could be done in less than an hour in order not to discourage the students from mathematics. Similarly, in their study Abdelfettah and Lam (2018) also concluded that mathematics homework that can be done within less than one hour increased academic development. The view that homework should take a short time to complete is supported by the findings of many studies in the literature (Baumgartnet et al., 1993; Büyükalan \& Altınay, 2018).

It was found to be remarkable that almost all of the teachers, who thought that math homework should be completed in less than an hour, were married and had at least one school-age child. It was assessed that the teachers who have children had this view as they observed and experienced the homework assigned to their own children at home. Baynazoğlu (2019) examined the opinions of classroom teachers on homework and concluded that teachers who had children gave different types of homework such as games and research assignments. This result was found to be striking and it was noted that there were no other studies with a similar finding. The teachers in the present study stated that they also tried to give homework right after each class and believed that assigning homework in this way was useful. Similarly, in a study conducted by Jong et al. (2000), it was concluded that teachers gave homework after each mathematics class. However, in the same study, it was also found that success was related to homework quantity, not homework frequency. Abdelfettah and Lam (2018) stated that assigning homework periodically rather than giving 
homework after each class was more suitable for academic success. In addition, Cooper et al. (2006) reported that assigning homework frequently was found to bore the students.

Some of the teachers stated that when preparing homework they focused on using different question types, made sure that the content of the homework is suitable for the outcome, used images that attracted the attention of the students, and arranged the questions in order from easy to difficult. Özer and Öcal (2013) argued that students should be given interesting assignments, otherwise they will get tired of them.

It is observed that all of the teachers distributed homework sheets by photocopying. The teachers explained that it was not possible for every student to access the Internet or obtain written sources. It can be stated that teachers try to provide equal opportunities to the students vie photocopying. Similarly, in the studies conducted by Akbaba and Tüzemen (2015) and Baynazoğlu (2018), it was determined that classroom teachers mostly distributed homework sheets to the students via photocopy.

\subsection{Purpose of the Homework}

It was observed that the goals of teachers for assigning homework in mathematics classes differed according to the function and type of homework. Most of the teachers aimed to assign homework in order to increase the academic development of the students, such as their understanding of the subject and ensuring knowledge retention. Similar to the results of the present study, Abdelfattah and Lam (2018), Brock et al. (2007) and Rosairo et al. (2015) determined that mathematics homework increased academic success. On the other hand, Kapıkıran and Kıran (1999) and, Güven and Akçay (2019) found that homework assignments for primary school students in mathematics class did not affect their academic success. Similarly, Jerrim et al. (2019) concluded that homework in primary education had no relationship with academic success. Güven and Akçay (2019) and Jerrim et al. (2019) reported homework frequency as the possible reason that made homework unffective on academic success. Fan et al. (2017) examined the studies conducted between 1986 and 2015 on the relationship between homework and mathematical success, and determined a strong relationship between the two in various countries and a weak relationship in others. Despite these findings, most of the studies that were reviewed showed that homework increased academic success (Baynazoğlu, 2019; Büyükalan \& Altınay, 2018; Büyüktokatlı, 2009; Cooper et al., 2006; Çelik \& Aktürk, 2009; Ersoy \& Anagün, 2009; Fernandez-Alonso et al., 2015; Güven \& Akçay, 2019; Jong et al., 2000; McMullen, 2007; Tertemiz, 1991; Xu et al., 2014). In this context, it was assessed that using homework in mathematics classes is important for the academic development of students.

Another function that teachers aim for when assigning homework is to make students use the new knowledge they have acquired in their daily life. Similarly, in the study of Büyükalan and Altınay (2018), it was determined that teachers believed that homework should be associated with daily life. The acquisition of daily life skills in mathematics class is very important for students to overcome the difficulties they encounter in life (Baykul, 2003). In this context, the fact that the teachers established a relationship between homework and daily life can be considered as a positive approach.

Some of the teachers stated that they aimed to make students aware of responsibility, provide them with problem solving skills, multidimensional thinking and operational practices, ensure they gained self-confidence by eliminating fear towards mathematics, encourage peer communication, facilitate individual learning, and help communication between family and children. It was observed that the teachers focused on personal development as well as academic development when assigning homework. However, they were more inclined to consider increasing academic development when preparing homework. The importance of homework in increasing personal development, especially the awareness of responsibility, has been explained and supported by many studies (Büyüktokatlı 2009; Canter \& Hausner, 1995; Duru \& Çöğmen, 2017; Johnson \& Pontius, 1989; Ok \& Çalışkan, 2019; Singh \& Fook, 2010; Taş et al., 2014). The 
studies conducted by Büyükalan and Altınay (2018), Canter and Hausner (1995) and Epstein (1983), showed that homework played a role that increased communication between the family and the student in primary school. In addition, Büyüktokatlı (2009) and Johnson and Pontius (1989) reported that doing homework helped students work independently. Büyükalan and Altınay (2018) also emphasized that math homework aimed to make students think more and argued that homework was also important in both individual and peer learning. The studies carried out by Çelik and Aktürk (2009) and Kapıkıran and Kıran (1999), showed that homework was an important element in peer communication. Goetz et al. (2012) reported that students' selfconfidence regarding homework and academic achievement were related, while Güven and Akçay (2019) found that homework improved problem solving skills. In this context, it was assessed that the findings of the present study were compatible with the related literature.

It was determined that almost all of the teachers gave math homework to reinforce the subject through repetition. The teachers were of the view that reinforcement through homework was very important for understanding the subject, especially in the mathematics class. They stated that these assignments were generally in the form of exercises. Many studies reported that teachers used homework assignments for reinforcement and repetition purposes (Abdelfattah \& Lam, 2018; Büyükalan \& Altınay, 2018; Ersoy \& Anagün, 2009; Ifflazoğlu \& Hizmetçi, 2006; Medwell \& Wray, 2018; Ok \& Çalışkan, 2019; Taş et al., 2014). Rosairo et al. (2015) stated that reinforcement type assignments increased the achievement levels in primary school mathematics class. Even though exercises aimed at reinforcement in mathematics class contribute to academic success, assigning exercises for reinforcement purposes only can discourage students from 21st century skills such as researching, building knowledge and creating products. For this reason, teachers should also give homework that require students to use analytical, critical and creative thinking skills in the math homework. In the present study, some of the teachers stated that they assigned homework as a preliminary preparation. Ersoy and Şengül (2009) and Van Voorsis (2004) determined that homework was assigned to prepare students for the next subject. These findings were compatible with the findings of the present study.

\subsection{Homework Evaluation Process}

It was observed that all of the teachers checked the mathematics homework, however some teachers didn't check the homework during class but preferred to check it after class during breaks. These teachers explained the reason for this as not wanting the time spent in class to be affected. On the other hand, the teachers who checked homework during class emphasized that checking homework took too much time, but must be done especially in the mathematics class. In this context, it was considered that the teachers cared about checking homework in mathematics class. Similarly, in the study conducted by Kaplan (2018), it was determined that all of the teachers checked the math homework. Aytuna (1998) and Büyükalan and Altınay (2018) also reported that checking homework was a part of the assignment process. These studies support the findings of the present study.

It was determined that almost all of the teachers gave feedback to the students for their math homework regardless of whether they did it incorrectly or could not do it. In this context, most of the teachers stated that they gave feedback for each incorrect or incomplete answer, while some of them corrected only the general mistakes. Some of the teachers stated that they gave detailed feedback for mathematics homework and only gave feedback in terms of scoring answers as true or false for other classes. Some teachers stated that they only checked whether the math homework was done or not. These teachers didn't give any feedback regarding false answers. The teachers who avoided giving individual feedback to the incorrectly done math homework stated that they aimed to save time in class. Similarly, Özer and Öcal (2013) concluded that teachers checked homework by giving feedback. In the studies conducted by Kaplan (2018) and Rosairo et al. (2019), it was determined that teachers only checked whether homework was done or not and did not give any feedback. Many studies have concluded that giving feedback on homework is important 
in terms of success and makes students attach importance to homework (Aytuna, 1998; Binbaş1oğlu, 1994; Laud \& Patel, 2013; Nunez et al., 2015; Tertemiz, 1991). In the present study, some teachers stated that they only checked whether the homework was done or not because the feedback process took too much time. In his study Ward (2019) emphasized that it took too much time to give feedback for homework. It was assessed that teachers considered giving feedback for homework to be important, however the fact that it takes too much time negatively affected the feedback process.

It was determined that the teachers mostly used the classroom board when giving feedback for homework. The teachers stated that they wrote down the questions that students had solved incorrectly or not been able to solve at all on the class board and aimed to ensure that all students could see the questions. It was also determined that some teachers used the smart board instead of the class board and solved the questions by projecting the homework to the smart board. It was observed that some teachers used mobile phones in terms of giving feedback. In this context, the teachers stated that they wanted to save class time by taking pictures of the homework on their mobile phones and checking the homework from the pictures. It can be stated that the teachers require alternative assessment methods to save class time. The study conducted by Dağ (2012), concluded that the feedback teachers provided for math homework that was shared via web-based applications had a positive effect on primary school students. Murphy et al. (2020) also stated that giving feedback on math problems via web-based applications increased the success levels of students. According to Stone (2014), web-based applications eliminated time and space limitations and giving feedback for homework by using these applications positively affected teacher performance and student participation. In this context, it was concluded that using web platforms for the process of giving feedback on homework could be an alternative solution to the time issue.

It was determined that some of the teachers rewarded the students who did their homework by giving them a star or a plus sign to encourage them. In cases where homework was not done, it was determined that most of the teachers punished the students in the form of a type two punishment. In this context, teachers stated that they deprived students from break time and social activity classes and asked them to complete the homework during these periods. Similarly, it was determined that some teachers did not assign homework to students who did not do homework for punishment purposes. Cooper (1989) discussed that not giving homework could be used for punishment purposes. Moreover, it was observed that some of the teachers assigned the same homework to the students who failed to do the homework and informed their families.

\subsection{Problems Encountered and Suggested Solutions}

It was determined that the problems the teachers encountered regarding the math homework process were mostly related to family-based issues. The teachers stated that they had problems due to the math homework being done by family members. As a solution to this, the teachers suggested to communicate with the families and get help from school counselors. Similarly, the study conducted by Ersoy and Anagün's (2009) concluded that homework was done by family members and teachers were uncomfortable with this situation. Many studies have revealed that family participation in homework is important in terms of academic success (Kurt \& Taş, 2019; Schumm, 2005; Silinskas \& Kikas, 2019; Turanl1, 2007; Trautwein, 2007; Xu et al., 2017). Patall et al. (2008) and Silinskas and Kikas (2017) determined that family interference in homework negatively affected the academic success of primary school students in mathematics class. Similarly, Cooper et al. (2000) found that the help of families regarding homework negatively affected the academic success of the students. The main problem rooted in all these studies was related to the way the help was given. Scott-Jones (1995) emphasized that families should act only as a guide and that the homework should be done by the student. He stated that families could only have a positive effect on the success of students by this way.

On the other hand, some teachers referred to the lack of an educational background of the families and their neglect towards students, as a family-based problem. The report of the Turkish 
Ministry of National Education, Department of Education, Research and Development (2011) published evaluated homework practices at primary school level and determined that families did not have enough information about homework subjects. A similar result was obtained by Davidovitch and Yavich (2017) who determined that in general, homework was considered as important by teachers and not so by parents. These studies support the findings of the present study.

It was found that some of the teachers encountered student-based problems. The teachers stated that the most important problem they had in this context was students not caring about homework. Some of the teachers who shared this view stated that the reason for this was due to fact that the homework was done by the family members. The studies conducted by Duru and Çöğmen (2017) and Kaplan (2018) concluded that the most common problem that teachers encountered during the homework assignment process was that students were not willing to do the homework. In the present study, the teachers suggested that homework should be assigned by taking into account personal differences, homework should be short and interesting, type two punishment should be applied when homework is not done, feedback should be provided in class, and homework follow-up should be done in cooperation with the family in order to ensure that students care about homework. The teachers also emphasized that students did not attach importance to homework as their families did not care about homework. It was also determined that students who did their homework were supported by their parents, while those that didn't do their homework were not supported in doing so. Cooper (1989) also found a high positive relationship between family attitude towards homework and student attitude. In this context, family attitude was assessed to be important on the behavior of students towards homework.

Some teachers stated that they had problems due to students failing to do problem solving type of homework. Some of the teachers stated that they ask students to create sample problems related to the relevant subject and expressed that these activities positively affected the students. Some of the teachers thought that solving different types of problems could be a solution to these issues. Holdener and Jones (2018), on the other hand, presented mathematical problems to students with the narrative method and obtained positive results.

Some of the participants stated that they had time-related problems when preparing homework as preparing homework takes too much time and is tiring. Therefore, as a solution, they suggested that the curriculum could be simplified and reduced.

It was observed that some of the teachers had problems with the fact that checking homework took up too much time. The teachers thought that the following solutions could be considered in order to use time efficiently: taking homework sheets from the students and checking them at home, focusing on successful students rather than all students, and making students solve math problems in social activity classes. In his study Kaplan (2018) similarly stated that teachers complained about the fact that checking math homework took too much time.

\section{Recommendations}

In this section, suggestions are made for practitioners and researchers, based on the results obtained from the research findings and considering the fact that the research has been carried out in a phenomenological design.

\subsection{Recommendations for Practitioners}

The teachers participating in the research should not leave the homework preparations for the mathematics lesson to the evening before the day or the hours of the lesson, but should prepare for the assignment in a wider time frame.

It was determined that the teachers participating in the study generally took their math homework ready from educational portals. It may be suggested to these teachers to prepare their own math homework. 
It was determined that the teachers participating in the study generally gave homework in practice type to reinforce the learning outcome. It may be suggested that these teachers also assign math homework that will help students improve their production and exploration skills.

Teachers participating in the study stated that they experienced problems because their math homework was done by family members. These teachers may be advised to frequently remind students and families about what harm this situation may cause.

Teachers participating in the study stated that the most important problem with students is that students do not care about homework. These teachers may be suggested to prepare homework for students that will solve a real problem of the student that is related to their daily life.

\subsection{Recommendations for Researchers}

Although this research provides an idea about the homework processes of classroom teachers in the mathematics course, more comprehensive research is needed to obtain more perfect and reliable data. In this context, studies using the observation method alongside the data collection method used in the research can be conducted to increase data diversity. Besides, only the experiences of primary school teachers regarding the phenomenon were examined in the study. In order to obtain more in-depth results, it would be appropriate to conduct research that examines students 'and their parents' experiences with primary school math homework. Besides, the researches to be conduct in the action research design related to the phenomenon examined in this study can provide the researchers with the opportunity to experience the phenomenon, so it may allow to reach more in-depth findings.

Disclosure statement. No potential conflict of interest was reported by the authors.

\section{References}

Abdelfattah, F. \& Lam, J. (2018). Linking homework to achievement in mathematics: An examination of 8th grade Arab participation in TIMSS 2015. International Journal of Instruction, 11(4), 607-624.

Akbaba, A., \& Tüzemen, M. (2015). İlkokul 1, 2 ve 3. sinıflarda ödev vermenin pedagojik boyutunun ilgili öğretmen görüşlerine göre değerlendirilmesi [Evaluating the pedagogical aspect of giving assignment in primary school 1st, 2nd, and 3rd grades based on teachers' views]. The Journal of Academic Social Science Studies, 32, 119-138.

Albelbisi, N. A. \& Yusop, F. D. (2018). Secondary school students' use of and attitudes toward online mathematics homework. Turkish Online Journal of Educational Technology-TOJET, 17(1), 144-153.

Arikan, Y. D. \& Altun, E. (2007). A research on preschool and primary student-teachers' use of online homework sites. Elementary Education Online, 6(3), 366-376.

Aytuna, H. A. (1998). Orta dereceli okullarda ögretmenlik ve problemleri [Teaching and problems in secondary schools]. MoNE Publications.

Babadoğan, C. (1990). Ev ödevlerinin eğitim programı içindeki yeri [The place of homework in the education program]. Ankara University Journal of Edeucational Sciences, 23(2), $745-767$. https://doi.org/10.1501/Egifak_0000000783

Baki, A. (2019). Matematiği öğretme bilgisi (2. baskı) [Knowledge of teaching mathematics (2nd ed.)]. Pegem.

Baumgartner, D., Bryan, T., Donahue, M. \& Nelson, C. (1993). Thanks for asking: parent comments about homework, tests, and grades, Exceptionality, 4(3), 177-185. https://doi.org/10.1207/s15327035ex0403_3

Baykul, Y. (2003). İlköğretimde matematik öğretimi 1-5 sınıflar için [Teaching mathematics in primary education for grades 1-5]. Pegem.

Baynazoğlu, L. (2019). Sınıf öğretmenlerinin ev ödevleri hakkındaki görüşlerinin incelenmesi [Investigation of classroom teachers' opinions on homework]. Milli Ĕğitim Dergisi, 48(221), 51-71.

Binbaşığlu, C. (1994). Genel öğretim bilgisi [General teaching knowledge]. Kadığlu Printing House.

Brock, C. H., Lapp, D., Flood, J., Fisher, D., \& Han, K. T. (2007). Does homework matter? An investigation of teacher perceptions about homework practices for children from nondominant backgrounds. Urban Educations, 42(4), 349-372. https:/ / doi.org/10.1177\%2F0042085907304277

Buyukalan, S. F. \& Altinay, Y. B. (2018). Views of primary teachers about homework (A qualitative analysis). Journal of Education and Training Studies, 6(9), 152-162. https:/ / doi.org/10.11114/jets.v6i9.3382 
Büyüktokatll, N. (2009). Examining Teachers' Views on Homework Practices in Primary Education [Unpublished master's thesis]. Selçuk University, Turkey.

Canter, L. \& Hausner, L. (1995). Devoirs sans larmes, Guide à l'intention de parents pour motiver les enfants à faire leurs devoirs et à réussir à l'école [Homework without tears, a guide for parents to motivate kids to do homework and succeed in school]. Les éditions de la Chenelière inc. http:/ / catalogue.cdeacf.ca/ Record.htm?record=19295730124910139129

Chandra, V. \& Fisher, D. I. (2009). Students' perceptions of a blended web-based learning environment. Learning Environment Research, 12, 31-44. https://doi.org/10.1007/s10984-008-9051-6

Chouinard, R., Archambault, J. \& Rheault, A. (2006). Les devoirs, corvée inutile ou élément essentiel de la réussite scolaire? [Homework, an unnecessary chore or an essential element of academic success?]. Revue des sciences del'éducation,32(2), 307-324. https:// doi.org/10.7202/014410ar

Cooper, H. (1989). Synthesis of research on homework. Educational Leadership, 11, 85-91.

Cooper, H. (2001). Homework for all - In moderation. Educational Leadership, 58(7), 34-39.

Cooper, H., Lindsay, J. J., \& Nye, B. (2000). Homework in the home: How student, family, and parentingstyle differences relate to the homework process. Contemporary Educational Psychology, 25, 464-487. https://doi.org/10.1006/ceps.1999.1036

Cooper, H., Robinson, J. \& Patall, E. (2006). Does homework improve academic achievement? A synthesis of research, 1987-2003. Review of Educational Research, 76, 1-62. http://www.jstor.org/stable/3700582

Creswell, J. W. (2013). Qualitative research methods. Qualitative research and research design according to five approaches (M. Bütün \& S. B. Demir, Trans.). Siyasal. (Orginal work published 2002)

Çelik, S. \& Aktürk, Z. (2009). An attempt to increase student performance in a classical classroom setting: Effects of seating arrangement and doing homeworks. Journal of National Education, 39(184), 37-43.

Dağ, E. (2012). Evaluating the homework of math lesson for fifth class students using web environments and researching the effectiveness of these environments on students, Education Sciences, 7(1), 466-475.

Davidovitch, N. \& Yavich, R. (2017). Views of students, parents, and teachers on homework in elementary school. International Education Studies, 10(10), 90-108.

Doğanay, A. , Türkoğlu, A., \& Yıldırım, A. (2009). Okulda başarı için ders çalışma ve öğrenme yöntemleri [Study and learning methods for success in school]. Seçkin.

Duru, S. \& Çöğmen, S. (2017). Views of primary and secondary school students and their parents on homework. Elementary Education, 16(1), 354-365.

Department of Education, Research and Development (2011). İlköğretim okullarındaki (1-5) ödev uygulamalarının değerlendirilmesi araştırması [Research on the evaluation of homework applications in primary schools (1-5)]. Ministry of https://www.meb.gov.tr/earged/earged/ilk_ok_odev_uyg_deg.pdf.

Emaikwu, S.O. (2011). Fundamentals of research methods and statistics. Selfers Academic Press.

Epstein, J. L. (1983). Homework practices, achievements and behaviors of elementary. ELT Journal, 27(5) 138143.

Ersoy, A. \& Anagün, Ş. S. (2009). Elementary teachers' views about homework process in science and technology course. Necatibey Faculty of Education Electronic Journal of Science and Mathematics Education, 3(1), 58-79.

Ersoy, A. F. (2016). Fenomenoloji [Phenomenology]. In A. Saban \& A. Ersoy (Eds.), Eğitimde nitel araştırma desenleri [Qualitative research patterns in education] (pp. 51-109). An1.

Fan, H., Xu, J., Cai, Z., He, J., \& Fan, X. (2017). Homework and students' achievement in math and science: A 30-year meta-analysis, 1986-2015. Educational Research Review, 20, 35-54.

Fernández-Alonso, R., Suárez-Álvarez, J. \& Muñiz, J. (2015). Adolescents' homework performance in mathematics and science: personal factors and teaching practices. Journal of Educational Pstchology, 107(4), 1075-1085. https://doi.org/10.1037/edu0000032

Goetz, T., Nett, U. E., Martiny, S. E., Hall, N. C., Pekrun, R., Dettmers, S., \& Trautwein, U. (2012). Students' emotions during homework: Structures, self-concept antecedents, and achievement outcomes. Learning and Individual Differences, 22(2), 225-234. https://doi.org/10.1016/j.lindif.2011.04.006

Güneş, F. (2014). Homework discussions in education. Bartın University Journal of Education Faculty, 3(2), 1-25.

Güven, U. \& Akçay, A. O. (2019). Trends of homework in mathematics: comparative research based on timss study. International Journal of Instruction, 12(1), 1367-1382.

Holdener, J. A., \& Jones, B. D. (2018). Calculus homework: a storied approach. Problems, Resources, and Issues in Mathematics Undergraduate Studies, 29(1), 21-42. https:/ / doi.org/10.1080/10511970.2017.1394946 
İflazoğlu, A. \& Hizmetçi, S. (2006, April). İlköğretim birinci kademe sımı öğretmenlerinin ev ödevleri hakkındaki görüşlerine ilişkin nitel bir çalışma örneği [A qualitative study example of primary school first grade teachers' opinions on homework] [Paper presentation]. National Classroom Teaching Congress, Ankara, Turkey. https:/ / www.pegem.net/Akademi/sempozyumbildiri_detay.aspx?id=8848

Jerrim, J., Lopez-Agudo, L. A. \& Marcenaro-Gutierrez, O. D. (2019). The relationship between homework and the academic progress of children in Spain during compulsory elementary education: A twin fixedeffects approach. British Educational Research Journal, 45(5), 1021-1049. https://doi.org/10.1002/berj.3549

Johnson, J. K. \& Pontius, A. (1989). Homework: A survey of teacher beliefs and practices. Research in Education, 41, 71-78. https:/ / doi.org/10.1177\%2F003452378904100108

Jong, R., Westerhof, K. J. \& Creemers, B. P. M. (2000). Homework and student math achievement in junior high schools. Educational Research and Evaluation, 6, 130-157. https://doi.org/10.1076/13803611(200006)6:2;1-E;F130

Kabapınar, Y., \& Yılmaz, D. (2020, March). Öğretmen adaylarinin matematik ile imtihanı: Bir türlü ısınamadım sana $x, y, z$ [Pre-service teachers' testing with mathematics: I couldn't get to know you $\mathrm{x}, \mathrm{y}, \mathrm{z}$ ] [Oral presentation]. FSMVU-ERC2020 Educational Research Congress, İstanbul, Turkey. https://eak2020.fsm.edu.tr/

Kapıkıran, Ş., \& Kıran, H. (1999). The effect of the homework on the students' academic success. Pamukkale University Journal of Education, 5, 54-60.

Kaplan, G. (2018). Opinions of students, teachers and parents about mathematics homework given to secondary school students [Unpublished master's thesis]. Hacettepe University,Turkey.

Kurt, U. \& Tas, Y. (2019). Prediction of students' strategies for doing science homework by parental support and students' goal orientation. Pegem Journal of Education and Instruction, 9(2), 585-604.

Kütükte, Z. (2010). Primary school teachers' perceptions, views and applications about performance and project assignments [Unpublished master's thesis]. Gaziosmanpaşa University, Turkey.

Landry-Cuerrier, J. \& Migneault, M. L. (2009). L'école, la famille et les devoirs [School, family and homework]. Vie Pédagogique, 151, 97. https://periscope-r.quebec/sites/default/files/fulltext/numero_151.pdf\#page $=97$

Laud, L. \& Patel, P. (2013). Getting started with formative assessment. In C. C. Collins. Using formative assessment to differentiate middle school literacy instruction (pp.1-17). Corwin.

Lopez, K. A., \& Willis, D. G. (2004). Descriptive versus interpretive phenomenology: Their contributions to nursing knowledge. Qualitative Health Research, 14(5), 726-735.

Mcmullen, S. (2007). The impact of homework time on academic achievement. http://citeseerx.ist.psu.edu/viewdoc/download?doi=10.1.1.529.2879\&rep=rep1\&type=pdf

Medwell, J. \& Wray, D. (2019). Primary homework in England: The beliefs and practices of teachers in primary schools. International Journal of Primary, Elementary and Early Years Education, 47(2), 191-204. https://doi.org/10.1080/03004279.2017.1421999

Murphy, R., Roschelle, J., Feng, M., \& Mason, C. A. (2020). Investigating efficacy, moderators and mediators for an online mathematics homework intervention. Journal of Research on Educational Effectiveness, 13(2), 235-270. https:// doi.org/10.1080/19345747.2019.1710885

Núñez, J. C., Suárez, N., Rosário, P., Vallejo, G., Cerezo, R., \& Valle, A. (2015). Teachers' feedback on homework, homework-related behaviors, and academic achievement. The Journal of Educational Research, 108(3), 204-216. https:// doi.org/10.1080/00220671.2013.878298

Ok, M. \& Çalışkan, M. (2019). Homework: opinions of teachers, students and parents. OPUS International Journal of Society Studies, 11(18), 594-620. https://doi.org/10.26466/opus.544599

Özer, B. \& Öcal, S. (2013). The evaluation of the applications and opinions of classroom teachers for homeworks. International Journal of Turkish Literature, Culture and Education, 2(1), 133-149.

Patall, E. A., Cooper, H., \& Robinson, J. C. (2008). Parent involvement in homework: A research synthesis. Review of Educational Research, 78(4), 1039-1101.

Patton, M. Q. (2018). Qalitative research \& evaluation methods (M. Bütün \& S. B. Demir, Trans.). Sage. (Orginal work published 2002). https://www.doi.org/10.14527/9786053649335

Rosário, P., Cunha, J., Nunes, A. R., Moreira, T., Núñez, J. C., \& Xu, J. (2019). “Did you do your homework?” Mathematics teachers' homework follow-up practices at middle school level. Psychology in the Schools, 56(1), 92-108. https:// doi.org/10.1002/pits.22198

Rosário, P., Núñez, J. C., Vallejo, G., Cunha, J., Nunes, T., Mourão, R., \& Pinto, R. (2015). Does homework design matter? The role of homework's purpose in student mathematics achievement. Contemporary Educational Psychology, 43, 10-24. https://doi.org/10.1016/j.cedpsych.2015.08.001. 
Rowell, L. L. \& Hong, E. (2002). The role of school counselors in homework intervention. Professional School Counseling, 5(4), 285.

Sart, G. (2015). Fenomenoloji ve yorumlayıc1 fenomenolojik analiz [Phenomenology and interpretive phenomenological analysis]. In F. N. Seggie \& F. Bayyurt (Eds.), Nitel araştırma yöntem, teknik, analiz ve yaklaşımları [Qualitative research methods, techniques, analysis and approaches] (pp. 70 - 81). Anı.

Schumm, J. S. (2005). How to help your child with homework: the complete guide to encouraging good study habits and ending the homework wars. Free Spirit Publishing.

Scott-Jones, D. (1995). Parent-child interactions and school achievement. In B. A. Ryan, G. R. Adams, T. P. Gullotta, R. P. Weissberg \& R. L. Hampton (Eds.), The family-school connection: Theory, research, and practice 2 ( pp. 75-107). Sage.

Serhan, D. \& Almeqdadi, F. (2020). Students' perceptions of using mymathlab and webassign in mathematics classroom. International Journal of Technology in Education and Science, 4(1), 12-17.

Silinskas, G. \& Kikas, E. (2017). Parental involvement in math homework: Links to children's performance and motivation. Scandinavian Journal of Educational Research,63(1), 17-37. https://www.tandfonline.com/doi/full/10.1080/00313831.2017.1324901

Silinskas, G. \& Kikas, E. (2019). Math homework: Parental help and children's academic outcomes. Contemporary Educational Psychology, 59, 101784. https://doi.org/10.1016/j.cedpsych.2019.101784

Singh, P., Sidhu, G.K., \& Chan, Y.F. (2013). Malaysian parents' practices and perspectives on the organization of school homework. Pertanika Journal of Social Science and Humanities, 21, 1019-1037.

Smith, J. A., Jarman, M., \& Osborn, M. (1999). Doing interpretative phenomenological analysis. In M. Murray \& K. Chamberlain (Eds.), Qualitative health psychology: Theories and Methods (pp. 218-240). Sage.

Smith, J., Flowers, P., \& Larkin, M. (2013). Interpretative phenomenological analysis. Theory, method and research (2nd ed.). Sage.

Sousa, P., Dias, P. C. \& Cadime, I. (2017). Predictors of primary school teachers' knowledge about developmental dyscalculia. European Journal of Special Needs Education, 32(2), 204-220. https:// doi.org/10.1080/08856257.2016.1216635

Stone, A. (2014). Online assessment: what influences students to engage with feedback? The clinical teacher, 11(4), 284-289. https:// doi.org/10.1111/tct.12158

Taş, Y., Sungur-Vural, S., \& Öztekin C. (2014). A study of science teachers' homework practices. Research in Education, 91, 45-64. https:/ / doi.org/10.7227\%2FRIE.91.1.5

Tertemiz, I.N. (1991). Ödevin başarıya etkisi [The effect of homework on success]. Education and Science, 81, 33-45.

Trautwein, U. (2007). The homework-achievement relation reconsidered: Differentiating homework time, homework frequency, and homework effort. Learning and Instruction, 17, 372-388. https:// doi.org/10.1016/j.learninstruc.2007.02.009

Turanll, A. S. (2009). Teachers' opinions about homework : A qualitative study on contextual factors. Çukurova University Journal of Education Faculty, 37(3), 129-143.

Van Voorhis, F. L. (2004). Reflecting on the homework ritual: Assignments and designs. Theory Into Practice, 43(3), 205-212. https://doi.org/10.1207/s15430421tip4303_6

Vatterott, C. (2010). Five hallmarks of good homework. Educational Leadership, 68(1), 10-15.

Voinea, M. \& Purcaru, M. (2015), Individual learning plan in teaching mathematics for children with sen - a constructivist approach. Procedia - Social and Behavioral Sciences, 187, 190 - 195.

Ward, E. L. (2019). Homework at the board: shifting feedback and responsibility. Problems, Resources, and Issues in Mathematics Undergraduate Studies (PRIMUS), 30(2), 230-242. https://doi.org/10.1080/10511970.2018.1542418

Xu, J., Yuan, R., Xu, B., \& Xu, M. (2014). Modeling students' time management in math homework. Learning and Individual Differences, 34, 33-42. https://doi.org/10.1016/j.lindif.2014.05.011

Yıldırım, O., Erdogan, T., \& Ciğdem, H. (2017). The investigation of the usability of web-based assignment system. Theory and Practice in Educational Sciences, 13(1), 1-9.

Yuniarti, Y., Kusumah, Y. S., Suryadi, D., \& Kartasasmita, B. G. (2017). The effectiveness of open-ended problems based analytic-synthetic learning on the mathematical creative thinking ability of pre-service elementary school teachers. International Electronic Journal of Mathematics Education, 12(3), 655-666. 